\title{
Assessment of Practices in Integrating Environmental Education in the Teacher Education Program
}

DOI: https://doi.org/10.47175/rielsj.v2i4.359

\section{| Rebecca Rosario O. Bercasio |}

\author{
Center for Teaching \\ Excellence, Bicol University, \\ Legazpi city, Philippines
}

rrobercasio@bicol-u.edu.ph

\begin{abstract}
The study aimed to assess the mainstreaming of environmental education in the Teacher Education curriculum. It used descriptive research design using qualitative approaches. Data were gathered using a rubric, documentary analysis, class observations, focus group discussion, and interview. Respondents and informants consisted of faculty-implementers, students, officials and administrative personnel. Each class in the different disciplines was observed by three class observers. The focus group discussion involved 35 students and the informal interview involved randomly selected class observers and key persons involved in the implementation of the project. Three dimensions were considered such as programmatic practices, organizational practices and context-specific practices. Assessment reveals the good practices in programmatic practices in terms of needs assessment and program design, in organizational practices in terms of governance, and context specific practices in terms of instructional materials development, delivery of the lesson, interaction with students, and assessment. Good practices serve as enabling factors for the successful mainstreaming of environmental education in the Teacher Education curriculum. Recommendations are provided to sustain the good practices and address those needing improvement.

KEYWORDS

assessment; environmental education; good practices; teacher education.
\end{abstract}

\section{INTRODUCTION}

The world continues to suffer due to environmental problems which contribute to the worsening of disasters due to climate change. Many countries face high risks due to these disasters and the Philippines ranked fourth in the countries most affected by disasters from 1999-2018 (Eckstein, Künzel, Schäfer, and Winges, 2019). With this, it becomes more urgent and relevant than ever to promote authentic and widespread environmental education (EE) among the different sectors. EE is important because it is not only about or in the environment, but more importantly learning for the environment (Glackin and King, 2020). It aims to develop an environmentally literate citizenry who is a key to resolving the environmental issues (North American Association for Environmental Education, 2004).

In the Philippines, Republic Act 9512 - National Awareness and Environmental Education Act of 2008 supports undertakings related to environmental education. This law calls on the education sector to take necessary action to do its share in the environmental education of various sectors of the society. This law supports collaboration between the Department of Environment and Natural Resources and academic institutions such as in interagency and multi-sectoral effort and capacity-building like the implementation of public education and awareness programs on environmental protection and conservation, trainings, 
seminars, workshops on environment education, development and production of environmental education materials, and teacher-education courses and related livelihood programs.

EE can be implemented in different manners, formally or informally in order to foster skills and habits that people can use throughout their lives to understand and act on environmental issues issues (North American Association for Environmental Education, 2004). Formally, it can be integrated in existing curricula as a "greening of the curriculum" (Emmanue and Ambe, 2014; Ajiboye and Ajitoni, 2008; Ormond, Zandvliet, McClaren, Robertson, Leddy and Metcalfe, 2014; Chimbodza and Ongevelle, 2004; Artun and Ozsevgec, 2016; Cutter-Mackenie and Edwards, 2010) or can be considered as a transversal theme in the curricula (Conde and Sanchez, 2010). Informally, EE can be implemented outside a prescribed or mandated curriculum or outside the classroom or school such as in eco-attractions (Dunkley, 2016), school gardens (Bowker and Tearle, 2007), forest conservation (Dickinson, 2011), botanical gardens (Drissner, Steigmüller and Hille, 2013) and place-based education (Dale, Powell, Stern and Garst, 2020).

EE frameworks are important to guide EE planning, implementation and evaluation, EE programs or interventions. Monroe, Andrews and Biedenweg (2007) have proposed a new framework for EE with the following purposes: convey information, build understanding, improve skills and enable sustainable action. Among its suggested formal and non-formal education strategies include active learning, collaborative learning, inquiry-based learning, problem-based learning, contextual learning, project-based learning, and service learning, information campaign, workshops, presentations, coaching mentoring , and adaptive collaborative management. Clark, Heimlich, Ardoin, and Braus (2020) have presented the five core outcomes for EE which are: (1) environmentally related action and behavior change, (2) connecting people to nature, (3) improving environmental outcomes, (4) improving social/cultural outcomes, and (5) learning environmentally relevant skills and competencies. They propose that environmental education works to move people to action for the tangible benefit of the environment and humanity. They argued that to realize these benefits, people must connect experientially with the environment, learn needed skills, and understand the complicated social and cultural connections between humanity and the natural environment. Wi and Chang (2019) have proposed a transformative climate change education (TrEC) curriculum that focuses on awareness, skills and values to help people understand environmental problems and inspire them to take environmental action.

Effective practices on EE program identified by Stern, Powell and Hill (2013) are: (1) active and experiential engagement in real-world environmental problems particularly issuebased, project-based, and investigation-focused programs in a real-world nature settings; (2) empowerment and student-centered learning; (3) social engagement such as cooperative group work; (4) emotional connections made during the program; (5) holistic experience; (6) focus on specific places and issues; (7) explicit linking of the program to students home lives; and (8) explicit provoking of student reflection. Experiential learning offered by ecoattractions which can help re-establish affective connections between the natural world and young people's everyday lives, and encouraged individuals to question their existing ecological knowledge, and explore and discuss sustainability further appears to be an effective approach to EE (Dunkley, 2016). Student-centered learning-teaching approaches based on learning by questioning-doing-living enable an active attendance in the learning environment and can establish a relationship with life and therefore should be preferred (Calis and Yildirim, 2020).

In the tertiary level, the Teacher Education program can aptly serve as a context for EE. The United Nations Educational, Scientific and Cultural Organization (UNESCO) identified 
teacher education programs and teacher educators as key players in the reorientation of education to address sustainability (Hopkins \& McKeown, 2005), besides the government has the responsibility to develop their capacity in teaching EE (Kimaryo, 2011). Since EE recognizes the importance of viewing the environment within the context of human influences, incorporating an examination of economics, culture, political structure, and social equity as well as natural processes and systems (North American Association for Environmental Education, 2004), the different disciplines under the Teacher Education program can be embedded with EE. Afterall, teachers with specializations other than environmental science or EE may effectively teach environmental lessons as integrations in their respective classes (Emmanue and Ambe, 2014).

Relatedly, there are challenges related to EE such as sustainability issues, the diffusion of curricula innovation in the secondary school sector and the potential resistance of lecturers to the implementation of integrated environmental education (Chimbodza and Ongevalle, 2004), and lack of teaching and learning facilities, time and wide class size (Kimaryo, 2011). It is also noted that stakeholders involved in the creation and implementation of EE modules were left feeling melancholy about what was deemed "dark matter" in the difficulties of introducing a true environmental learning practice group (Ormond, Zandvliet, McClaren, Robertson, Leddy and Metcalfe, 2014).

The implementation of EE mainstreaming requires evaluation. Limbani, Goudge, Joshi, et al. (2019) have argued that process evaluation has an important role in understanding implementation process of complex interventions. They stated that process evaluation is crucial in understanding contextual factors that may impact intervention implementation which is important in considering whether the intervention can be translated to other contexts. Part of the process evaluation of the EE mainstreaming in the Teacher Education program is assessing the practices. The Department of Environment and Natural Resources (DENR) collaborated with a state university in a project on the mainstreaming EE in the different disciplines in the Teacher Education curriculum from 2016 to 2018. In its implementation, the assessment of practices in the different dimensions of the EE mainstreaming in the Teacher Education curriculum is important as part of the process evaluation.

Practices are defined as particular ways of doing things which may encompass a whole program or may simply refer to single method or way of looking at things (Work Group for Community Health and Development, University of Kansas, 2016). Similarly, practices may be defined as a program, activity, or strategy. A practice can also be a system, methodology, process, formula, technique, tactic, or approach. The six key dimensions of best practices are programmatic practices, organizational practices, generalizable practices, context specific practices, present need practices and future need practices (National Resource Center, 2010).

This study aimed to assess the practices in the EE mainstreaming in the teacher education program in terms of programmatic practices, organizational practices, and context-specific practices. It also aimed to determine the specific good practices in these different dimensions.

\section{RESEARCH METHODS}

This research used descriptive research design using qualitative approaches. The descriptive research was used to assess the practices in the mainstreaming of EE in the Teacher Education program in a state university in the Philippines from 2016-2018. Documentary analysis, class observations, focus group discussion, and interview were used to gather data on the practices in the different dimensions. Each class in the different disciplines was 
observed by three class observers. The focus group discussion involved 35 students and the informal interview involved randomly selected class observers and key persons involved in the implementation of the project.

Sources of data included the documentation and project reports, class observation notes, focus group discussions with students, and responses to interview. Data gathering tools included rubric on assessing the practices, class observation tool, and FGD and interview guide guides.

Data analysis on the practices was done using a validated researcher-made rubric. The criteria considered for determining good practices are effectiveness, replicability and adaptability, relevance, sustainability (economic and social), technical feasibility, and gender sensitivity. The analysis of the areas per dimension was guided by the following: (1) All criteria are met - Good Practice; (2) Some criteria are met - Promising Practice; and (3) No criterion is met - Emerging Practice. If the area under a specific dimension is not applicable, write NA. Data from class observations, the transcription of the focus group discussion, and the responses to interview, and project reports were analyzed using manual coding.

\section{RESULTS AND DISCUSSION}

In this study, the practices refer to the specific ways of doing, activities or strategies in the mainstreaming of EE in the Teacher Education curriculum. Three dimensions are considered; namely, programmatic practices, organizational practices, and context specific practices. The programmatic practices include those parts of an organization involved in responding to an issue or problem through some type of service. Under this, seven areas are considered; namely, needs assessment, program design, work plans, project management, information and reporting system, volunteer recruitment and evaluation. The organizational practices include those areas of the organization that impact the effective implementation and management of the programs. Under this, three areas are considered such as governance, financial and grant management, and partnership and collaboration. Lastly, the context specific practices apply only to those organizations working in a specific context, that is, in the academe or educational setting. As such, the areas considered under this dimension are those aspects which influence the teaching and learning process in EE. These are as follows: Instructional Materials, Instructional Strategies/ Delivery of Lessons, Interaction with students, and Assessment.

A good practice is one that has been proven to work well and produce good results and is therefore recommended as model. It is a successful experience that has been assessed and validated, in the broad sense, has been repeated and deserves to be shared, so that a greater number of people can adopt it (FAO, 2016). In this study, the practices were assessed considering effectiveness, replicability and adaptability, relevance, sustainability (economic and social), technical feasibility, and gender sensitivity.

In terms of needs assessment, it was deduced from the data that the conduct of pre-test can be considered as a good practice. This was noted in the conduct of pre-test to the students which was administered well with the cooperation of all concerned. It is also important to note that the assessment tools used were parallel for the different disciplines and covered the environmental concepts and principles tackled in the lessons to be pilot tested. In the absence of a list of environmental competencies sequenced in spiral progression in the different levels in the different courses or subjects, the most reasonable basis of an assessment tool is the coverage of the lessons. The test also included a part for self-assessment giving the students the opportunity to reflect on their understanding. Though the tests did not undergo a dry-run as this pilot testing served as its wide-scale dry-run, they underwent critiquing and revisions 
based on the validated table of specifications. To reiterate, the conduct of the needs assessment was done observing the principles of test development and administration. Therefore, the conduct of needs assessment is considered effective, replicable and adaptable, relevant, sustainable, technically feasible and gender sensitive. The needs assessment specifically attained its target of measuring the level of understanding and competence of the students in terms of the different environmental concepts and principles. With the tools easily available, this can be replicated and adapted and are relevant for other environmental education integration in other academic programs. The use of such assessment tools for a similar undertaking is sustainable both economically and socially because it will not comprise financial standing of the organization nor will it compromise the ability of the organization to serve other clients. Technically speaking, the test is easy to administer, score, and interpret. Finally, the test does not have gender preference or bias as it is appropriate for either male or female.

Table 1. Assessment of practices in the mainstreaming of EE in the teacher education program in terms of programmatic practices

\begin{tabular}{|c|c|c|c|c|c|c|c|}
\hline \multirow{2}{*}{ Areas } & \multicolumn{6}{|c|}{ Criteria } & \multirow{2}{*}{$\begin{array}{c}\text { Description of } \\
\text { the Practice }\end{array}$} \\
\hline & 1 & 2 & 3 & 4 & 5 & 6 & \\
\hline Needs Assessment & $\checkmark$ & $\checkmark$ & $\checkmark$ & $\checkmark$ & $\checkmark$ & $\checkmark$ & Good \\
\hline Program Design & $\checkmark$ & $\checkmark$ & $\checkmark$ & $\checkmark$ & $\checkmark$ & $\checkmark$ & Good \\
\hline Work Plan & NA & $\mathrm{x}$ & $\mathrm{x}$ & $\mathrm{x}$ & $\mathrm{x}$ & $\mathrm{x}$ & Emerging \\
\hline Project Management & $\checkmark$ & $\checkmark$ & NA & $\mathrm{x}$ & $\mathrm{x}$ & $\checkmark$ & Promising \\
\hline Information or reporting system & $\mathrm{x}$ & $\mathrm{x}$ & $\checkmark$ & $\sqrt{ }$ & $\mathrm{x}$ & $\mathrm{x}$ & Promising \\
\hline Volunteer Recruitment & $\mathrm{x}$ & NA & $\checkmark$ & $\mathrm{x}$ & $\mathrm{x}$ & $\mathrm{x}$ & Promising \\
\hline Program Evaluation & $\mathrm{NA}$ & NA & NA & $\mathrm{NA}$ & NA & NA & \\
\hline
\end{tabular}

Legend: 1-effectiveness, 2-replicability and adaptability, 3-relevance, 4-sustainability (economic and social), 5-technical feasibility, and 6-gender sensitivity; $\checkmark$-Yes, $x$-No, NA-Not applicable.

Like the needs assessment, the program design which was a product of a research undertaking is considered a good practice. The design of the program which refers to the mainstreaming of EE in the Teacher Education curriculum is a result of a rigorous academic process of reviewing the curriculum which was done by analyzing all the syllabi for all the courses. Through this, the points of integration for EE were identified. Moreover, the DENR EE materials were also assessed so that the specific environmental concepts or principles could be identified. To facilitate the implementation of the program, a guide in the form of Curriculum Guides were available for each discipline. The rigorous process involved collaborative activities of the different stakeholders. The design of the program is therefore considered as a good practice because it attained its purpose, can easily be replicated, relevant to the needs of the clients and even to the organizers/implementers since any environmental concern is everyone's concern, is both economically and socially sustainable, can be easily implemented, and does not dent on gender prejudice against women.

Other practices pertaining to project management, information and reporting system and volunteer recruitment were observed to have the potential of effectively addressing issues and concerns of clients and different stakeholders. These were found to be promising practices. The practice related to the work plan which was done with specific committee and in consultation with the funding agency was not considered currently as a promising or good practice. Repetitive revisions and delays were experienced by the implementing agency. This could be due to unavoidable differences in the interpretation of certain processes or protocols. This area however could pave the way to a promising practice in the future similar engagement. One area which is program evaluation was noted as inapplicable currently since this was not yet done. What was done was the pilot testing of the EE-enriched session plans, 
and not exactly the evaluation of the program using a highly acceptable model for evaluation. The program evaluation may ensue after its completion.

In terms of practices pertaining governance, it was clearly observed that the management of the institution addressed the issues and concerns relative to the implementation of the project. For instance, an area or office has been provided to serve as the workstation of the project team. Meetings, consultations, and workshops were facilitated to ensure that the targets are met despite financial constraints. The members of the project team were issued designations thus officially recognizing the participation of all concerned. All the facultyresearchers concerned have well-defined work and deliverables, and commensurate compensation. Assistance was readily available from the top management and consultants, the accounting office as well as the legal office for the different issues confronted ensuring that project would attain its target without compromising welfare of the persons involved or of the agencies involved.

Table 2. Assessment of practices in the mainstreaming of EE in the teacher education in term of organizational practices

\begin{tabular}{|c|c|c|c|c|c|c|c|}
\hline \multirow{2}{*}{ Areas } & \multicolumn{6}{|c|}{ Criteria } & \multirow{2}{*}{$\begin{array}{c}\text { Description of the } \\
\text { Practice }\end{array}$} \\
\hline & 1 & 2 & 3 & 4 & 5 & 6 & \\
\hline Governance & $\checkmark$ & $\checkmark$ & $\checkmark$ & $\checkmark$ & $\checkmark$ & $\mathrm{x}$ & Good \\
\hline Financial /Grant Management & $\mathrm{x}$ & $\mathrm{x}$ & $\mathrm{x}$ & $\mathrm{x}$ & $\checkmark$ & $\checkmark$ & Promising \\
\hline $\begin{array}{l}\text { Participation of/ Collaboration with } \\
\text { Stakeholder }\end{array}$ & $\checkmark$ & $\mathrm{x}$ & $\mathrm{x}$ & $\mathrm{x}$ & $\checkmark$ & $\checkmark$ & Promising \\
\hline
\end{tabular}

Legend: 1-effectiveness, 2-replicability and adaptability, 3-relevance, 4-sustainability (economic and social), 5-technical feasibility, and 6-gender sensitivity; $\checkmark$-Yes, $x$-No, NA-Not applicable.

In terms of financial and grant management, some processes were noted to be good practices while others were observed to be promising practices. A case to cite is the delayed release of budget therefore delaying the wages of the full-time project staff as well as the honoraria of the researchers. It is understood that certain reasons must have caused the delay however assessing such practice will not certainly yield a good description. However, this could be addressed better in the future similar engagement therefore this can be considered as a promising practice.

Similarly, the current practice of having a cut-off period for the preparation of financial reports proved to be a hindering factor rather than an enabling one. An illustration of this is the delayed preparation, finalization, and submission of the liquidation report as required by the funding agency (though not necessary provided in the approved memorandum of agreement) due to the contention of the person/s involved that it was not yet the cut-off period (though it was supposed to be considered as a backlog since financial transactions were already way after the approved timetable). These practices hindered attainment of targets as scheduled, therefore not considered effective nor an exemplar to be adapted and were not highly responsive to the needs of the project team or implementers.

Additionally, in terms of sustainability, though technically the project terminates based on the agreement of the two agencies, it was specifically provided that part of the responsibility of Bicol University is to continue the BU-DENR Environmental Education Learning Resource Center as a functional unit in the University and in the $3 \mathrm{NS}$. The University, recognizing the significance of the center, has expressed favorable support to this especially with the office still existing, hence this is viewed as a promising practice.

Lastly, in terms of gender sensitivity, the project and the Center created as its result provide equitable opportunity for both women and men for participation and collaboration. The activities conducted were noted to be gender fair since students regardless of gender 
were given opportunity to maximize their participation, while implementers, class observes and project staff consisted of both male and female, even with female dominating the team. Overall, the practices pertaining to financial and grant management was assessed as promising.

In terms of participation and collaboration with stakeholders, some practices were observed as good while others as promising. The involvement of an external funding agency, of the different colleges and offices of the University, as well as of students from different disciplines reveal from different 3NS institutions reveal the multi-dimensional nature of the project on environmental education. The active participation especially of students and the teacher-implementers and class observers contributed to the success of the project, thus gauging its effectiveness. Whether all these individuals involved will participate in the replication of this project out of volunteerism and advocacy, and as a relevant part of their future workload, cannot be ascertained as of this writing, hence this can be described as promising. In terms of sustainability of the participation and collaboration, it can also be described as promising since without external funding support, the participation may not be compensated financially but rather experientially towards further development and selfactualization. On the whole, participation and collaboration can be considered as promising.

Table 3. Assessment of practices in the mainstreaming of EE in the teacher education in term of context- specific (Teaching and Learning) practices

\begin{tabular}{|c|c|c|c|c|c|c|c|}
\hline \multirow{2}{*}{ Areas } & \multicolumn{6}{|c|}{ Criteria } & \multirow{2}{*}{$\begin{array}{l}\text { Description of the } \\
\text { Practice }\end{array}$} \\
\hline & 1 & 2 & 3 & 4 & 5 & 6 & \\
\hline Instructional Materials & $\checkmark$ & $\checkmark$ & $\checkmark$ & $\checkmark$ & $\checkmark$ & $\checkmark$ & Good \\
\hline $\begin{array}{l}\text { Instructional Strategies/ } \\
\text { Delivery of Lessons }\end{array}$ & $\checkmark$ & $\checkmark$ & $\checkmark$ & $\checkmark$ & $\checkmark$ & $\checkmark$ & Good \\
\hline Interaction with students & $\checkmark$ & $\checkmark$ & $\checkmark$ & $\checkmark$ & $\checkmark$ & $\checkmark$ & Good \\
\hline Assessment & $* \sqrt{ }$ & $\checkmark$ & $\sqrt{ }$ & $\checkmark$ & $\checkmark$ & $\checkmark$ & Good \\
\hline
\end{tabular}

Legend: 1-effectiveness, 2-replicability and adaptability, 3-relevance, 4-sustainability (economic and social), 5-technical feasibility, and 6-gender sensitivity; $\checkmark$-Yes, $x$-No, NA-Not applicable.

As previously stated, these practices apply only to those organizations working in a specific context, in this case, in the academe or educational setting. Therefore, the areas considered under this dimension are those aspects which influence the teaching and learning process in EE which are the following: Instructional Materials, Instructional Strategies/ Delivery of Lessons, Interaction with students, and Assessment.

The qualitative analysis of the data reveals that good practices were observed in the four areas. For instructional materials, it was particularly observed that the availability of the materials facilitated the delivery of the lessons. Though at the start it was noted that majority of the session plans did not include the specific instructional materials mentioned, the concerned teacher-implementers with the assistance of the project assistants either searched or prepared the necessary instructional materials both for the lesson and the EE integration or tasks. Addressing the gap in the packaging of the session plans, the implementers were generally able to deliver the lessons, thus attaining the objectives of the lessons. In particular, the integration of environmental concepts and principles was observed to be easy when the session plan together with all the materials needed is available. The availability of adequate materials which were used during the EE Integration part of the lesson especially made the work of the teacher easy. The EE instructional materials available consisted of the DENR pamphlets and brochures which were either scanned or encoded and included as part of the PowerPoint presentation or presented as handouts, and of the researcher searched and/or 
developed printed EE materials such as the session plans and worksheets, and non-print EE materials such as PowerPoint presentations, PowerPoint-based games and videos.

Similarly, it is noted that through the DENR EE materials, the mandates, advocacies, initiatives and programs of the department were disseminated to the students. In this way, the students become more informed of environment-related issues and concerns which may affect their behaviors and attitudes. Considering that these EE materials played a crucial role in the successful delivery of the lessons in the different disciplines, the development of EE materials as well as the sharing of EE materials by the DENR were highly appreciated by the implementers and the students and is therefore noted as a good practice.

Nevertheless, in terms of the DENR EE materials, it was noted that only one set of materials was given to the university and based on the experiences of the implementers and even students, many materials are still available in print. This means that the implementers will either change them to electronic version or re-encode necessary information in presentation to become attractive to the students who are generally digitally inclined. The limited number of copies of the print EE materials posed a challenge to the project team. Likewise, the limited number of non-print EE materials from DENR clearly indicates the need to pursue the undertaking on ICT- based EE materials development. In addition, the teacher implementers, observers, and students noted that majority of the DENR EE materials especially the print materials in their current form need to be enhanced in order to become useful for instructional purposes. Therefore, this is specifically noted as a promising practice.

The delivery of lessons was noted as significantly dependent on the teacher. Class observers and students noted that mastery of the lesson and of the EE concept/principle integrated by the teacher facilitates the conduct of the different learning tasks in the different disciplines. One observer, for instance, said, "Teacher's preparedness and mastery of both the lesson and the environmental concept or principle/s facilitate the conduct of the lesson." Using varied activities was also noted as a good practice in terms of the delivery of the lessons. Students claimed that they were "encouraged to participate because the activities are not similar always." The different activities involved in the EE integration utilized learner-centered approaches featuring varied learning tasks or activities using active learning and collaborative learning strategies. Class observers also noted that EE integration

Class observers also noted that EE integration was given adequate time therefore EE concepts and principles were processed well. One comment related to this says, "The EE concept or principle is processed through interactive activities and/or assessment tasks." It is noted that the EE integration was allotted approximately 20 or 25 to 40 minutes including the discussion and the activities. The delivery of the lessons involved strategies and learning tasks which are learner-centered and aligned to the objectives. These strategies are anchored on the model for the mainstreaming of EE in the Teacher Education curriculum and included active learning strategies, collaborative learning strategies, contextual learning and others. The learning tasks are varied and responds to the diversity of the students, not to mention that technology was utilized to enhance and/or facilitate the teaching-learning process. Therefore, the delivery of the lessons by competent teachers can be considered as a good practice.

Table 4. Specific good practices in the mainstreaming of environmental education in the teacher education program

\begin{tabular}{|l|l|}
\hline \multicolumn{1}{|c|}{ Area } & \multicolumn{1}{c|}{ Specific Good Practices Observed/Noted by Stakeholders } \\
\hline Programmatic Dimension \\
\hline $\begin{array}{l}\text { Needs } \\
\text { Assessment }\end{array}$ & $\begin{array}{l}\bullet \text { Needs assessment was conducted using juror-validated tool with a Table of } \\
\text { Specifications }\end{array}$ \\
\hline
\end{tabular}




\begin{tabular}{|c|c|}
\hline Program Design & $\begin{array}{l}\text { - The EE- enriched session plans and curriculum guide was a research } \\
\text { validated program which were found ready for pilot-testing. }\end{array}$ \\
\hline \multicolumn{2}{|c|}{ Organizational Practices } \\
\hline Governance & $\begin{array}{l}\text { - The management of the institution addressed the issues and concern relative } \\
\text { to the implementation of the project. Meetings, consultations and workshops } \\
\text { were facilitated to ensure that target are met despite financial constraints. } \\
\text { - The members of the project team were issued designations well-defined work } \\
\text { and deliverables and commensurate compensation thus officially recognizing } \\
\text { the participation of all concerned. } \\
\text { - Assistance was readily available from the top management and consultants, } \\
\text { the accounting office as well as the legal office for the different issues } \\
\text { confronted. }\end{array}$ \\
\hline \multicolumn{2}{|c|}{ Context Specific Practices } \\
\hline $\begin{array}{l}\text { Instructional } \\
\text { Materials } \\
\text { Development }\end{array}$ & $\begin{array}{l}\text { - Adequate materials prepared and/or searched by teacher implementers and } \\
\text { project staff facilitate the EE integration. } \\
\text { - Using appropriate ICT materials such as PPT presentations, videos and } \\
\text { electronic version of DENR EE materials facilitate the EE integration. } \\
\text { - Using the DENR EE materials serves as a help in disseminating the materials } \\
\text { and the initiatives and programs of the department which are not common } \\
\text { exposed through the mass media. }\end{array}$ \\
\hline $\begin{array}{l}\text { Delivery of the } \\
\text { Lessons }\end{array}$ & $\begin{array}{l}\text { - Teacher's preparedness and mastery of both the lesson and the environmental } \\
\text { concept or principle/s facilitate the conduct of the lesson. } \\
\text { - Using varied strategies which encourage active learning encourages students' } \\
\text { participation. } \\
\text { - The EE concept or principle is processed through interactive activities and/or } \\
\text { assessment tasks. }\end{array}$ \\
\hline $\begin{array}{l}\text { Interaction with } \\
\text { Students }\end{array}$ & $\begin{array}{l}\text { - Students are well informed of the objectives of the environmental education } \\
\text { integration and its relevance to them as students and future professionals } \\
\text { - Teacher made a sincere emotional connection with the student as a mentor. } \\
\text { - Showing commitment to the EE advocacy through the lecture or through } \\
\text { project implementation by the concerned teacher and school officials } \\
\text { motivate students to perform their responsibilities and become committed, too. }\end{array}$ \\
\hline Assessment & $\begin{array}{l}\text { - Interactive assessment tasks either individual, pair and group encourage } \\
\text { student participation. } \\
\text { - Game-based assessment technique reduces students' anxiety towards } \\
\text { assessment. } \\
\text { - Varied assessment techniques address students' diversity. }\end{array}$ \\
\hline
\end{tabular}

Another good practice noted deal on the implementer's interaction with the student participants. The students are the primary beneficiaries of the EE-enriched lessons. During the opening program and orientation, the students were informed of the significance and purpose of the lecture-series. Having realized the objectives of the environmental education integration and its relevance to them as students, future professionals and as citizens, the students took their participation seriously and considered their engagement as a form of enhancement. Moreover, it was noted that committed participation of teacher and school officials motivated the students to participate actively and perform their responsibilities as participants. In particular, a connection between the teacher and the students appeared to have helped sustain the commitment of the students. Both informing students of the purposes and relevance of EE integration, showing exemplar of commitment to $\mathrm{EE}$ and served establishing an emotional connection served as precursors for the active and committed 
participation of the students. These practices therefore can be considered as contributor to the success of the EE integration in the Teacher Education

In terms of assessment, the use of formative assessment was noted as a good practice. These formative assessment tasks, either individual, pair and group, encouraged student participation and were observed to be interactive. Observers noted that even the students who are generally passive participated in the various activities. For instance, the use of the game-based assessment task encouraged the students to participate in the task while enjoying at the same time. The simulation of the quiz bee competition resulted to a relaxed atmosphere in the classroom hence the anxiety of the students towards assessment was reduced.

Class observers also noted that using varied assessment techniques addressed the student's individual differences. The use of individual, pair and group activity either in written or oral form or both was a way of inclusivity in the class since students of different learning styles and personality had the avenue for participation. Most importantly, in these assessment tasks, the students had the opportunity to assess their comprehension of the EE concept or principle, and to transfer learning in similar or related situations.

\section{CONCLUSION}

The mainstreaming of EE in the Teacher Education program supports the national law on the promotion of environmental awareness and education. Although its transversal integration in the Teacher Education is yet to be implemented on a national scale, its pilot implementation has shown strong potentials. The assessment of the practices in the EE mainstreaming in the Teacher Education program has shown more promising practices in terms of programmatic practices and organizational practices. Moreover, in terms of contextspecific practices, that is, teaching and learning, good practices have been noted in all the four dimensions such as instructional materials development, delivery of the lesson, interaction with students, and assessment serve. These good practices served as enabling factors for the successful mainstreaming of EE in the Teacher Education curriculum. The dissemination of the good practices to other TEIs is strongly recommended. Further research recommended include follow-up study on how the teacher education students' attitudes towards the environment have been changed, application of the environmental principles and concepts gained from the lessons, addressing gender issues related to the EE integration in the lessons, materials and assessment tools, development of EE Module for Pre-service Teachers and/or a Training Model on EE for Pre-service Teachers and development of other $\mathrm{EE}$ lessons or intervention focusing on place as a dimension for contextualization of EE (Condeza-Marmentini, 2020), environmental philosophies (Haydock, and Srivastava, 2019), time spent on the program as positive effects increase with time (Lindemann-matthies, 2010), promotion of collective responsibility in EE (Aarnio-Linnanvuori, 2019), and examination of EE practice innovations at the group rather than individual level ( $\mathrm{Li}$ and Kransy, 2019).

\section{ACKNOWLEDGMENT}

We are grateful to the Republic of the Philippines-Department of Environment and Natural Resources for the grant, the Bicol University, the respondents and informants consisted of faculty-implementers, students, officials and administrative personnel.

\section{REFERENCES}

Aarnio-Linnanvuori, E. (2019). How do teachers perceive environmental responsibility?. Environmental Education Research, 25(1), 46-61. https://doi.org/10.1080/13504622.2018.1506910 
Ajiboye, J. O., \& Ajitoni, S. O. (2008). Effects of full and quasi-participatory learning strategies on Nigerian senior secondary students' environmental knowledge: Implication for classroom practice. International Journal of Environmental \& Science Education, 3, 58-66. http://www.ijese.net/makale/1628.html

Artun, H., \& Ozsevgec, T. (2016). A study on the evaluation of the applicability of an environmental education modular curriculum. International Journal of Environmental \& Science Education, 11(5), 7318-7347. http://www.ijese.net/makale/1003.html

Bowker, R., \& Tearle, P. (2007). Gardening as a learning environment: A study of children's perceptions and understanding of school gardens as part of an international project. Learning Environments Research, 10(2), 83-100. http://doi:10.1007/s10984-007-9025-0

Calis, D. \& Yildirim, H.I. (2020). The Effect of Prediction, Observation, Explanation Supported Project-Based Environmental Education on the Levels of Attitude and Behavior Toward the Environment. Educational Policy Analysis and Strategic Research, 15(1), 22-43. https://doi.org/10.29329/epasr.2020.236.2

Chimbodza, I. \& Ongevelle J. (2004). Environmental education in action in secondary teacher training in Zimbabwe. Southern African Journal of Environmental Education 21, 108-119. https://www.ajol.info/index.php/sajee/article/view/122685

Clark, C.R., Heimlich, J.E. Ardoin, N.M. \& Braus, J. (2020). Using a Delphi study to clarify the landscape and core outcomes in environmental education. Environmental Education Research, 26(3), 381-399. https://doi.org/10.1080/13504622.2020.1727859

Conde, M. D. C., \& Sanchez, J. S. (2010). The school curriculum and environmental education: A school environment audit experience. International Journal of Environmental \& Science $\quad$ Education, 574-494. https://files.eric.ed.gov/fulltext/EJ908944.pdf

Condeza-Marmentini, A. (2020). Configurations of environmental knowledge: Place as pedagogical experience and community action. Environmental Education Research. 26(3), 454 - 455. https://doi.org/10.1080/13504622.2020.1736271

Cutter-Mackenie, A. \& Edwards, S. (2013). Towards a model for early childhood environmental education: foregrounding, developing, and connecting knowledge through play-based learning. The Journal of Environmental Education, 44 (3),195-213. https://doi.org/10.1080/00958964.2012.751892

Dale, R., Powell, R, Stern, M. \& Garst, B. (2020). Influence of the natural setting on environmental education outcomes. Environmental Education Research, 26 (5), 613631. https://doi.org/10.1080/13504622.2020.173846

Dickinson, E. (2011). Displaced in nature: The cultural production of (non-) place in placebased forest conservation pedagogy. Environmental Communication: A Journal of Nature and Culture, 5(3), 300-319. https://doi:10.1080/17524032.2011.584889

Drissner, J., Steigmüller, M. L., \& Hille, K. (2013). Environmental education outside school: Effects of a half-day teaching programme. Education Journal, 2(6), 231-235. https://doi:10.11648/j.edu.20130206.14

Dunkley, R. (2016). Learning at eco-attractions: Exploring the bifurcation of nature and culture through experiential environmental Education. The journal Environmental Education, 47(3),213-221. https://doi:10.1080/00958964.2016.1164113

Eckstein,D., Künzel, V., Schäfer, L, \& Winges, M. (2019). Global climate risk index 2020. Bonn: Germanwatch e.V. www.germanwatch.org/en/cri

Emmanue, I. \& Ambe, B. (2014). Influence of teachers, professional qualification and area of specialization on the implementation of environmental education curriculum in Cross River State - Nigeria. Proceedings of the International Conference on Chemical, Environment \& Biological Science. 155-160. http://dx.doi.org/10.15242/IICBE.C914120 
English oxford living dictionary. https://en.oxforddictionaries.com/definition/practice FAO (2016). Good practice template. http://www.fao.org/docrep/019/as547e/as547e.pdf.

Glackin, M., \& King, H. (2020). Taking stock of environmental education policy in England - the what, the where and the why. Environmental Education Research, 26(3), 305-323. https://doi.org/10.1080/13504622.2019.1707513

Haydock, K. \& Srivastava, H. (2019). Environmental philosophies underlying the teaching of environmental education: A case study in India. Environmental Education Research, 25(7), 1038-1065. https://doi.org/10.1080/13504622.2017.1402170

Hopkins, C. \& McKeown, R. (2005). Guidelines and recommendations for reorienting teacher education to address sustainability. UNESCO Education for Sustainable Development in Action Technical Paper No. 2. https://unesdoc.unesco.org/ark:/48223/pf0000143370

Kimaryo, L. (2011). Integrating environmental education in primary school education in Tanzania: Teachers' perceptions and teaching practices. Abo Akademi University Press. https://www.doria.fi/bitstream/handle/10024/67481/kimaryo_lydia.pdf?...1

Limbani, F., Goudge, J., Joshi, R. et al. Process evaluation in the field: global learnings from seven implementation research hypertension projects in low-and middle-income countries. BMC Public Health 19, 953 (2019). https://doi.org/10.1186/s12889-019-7261-8

Lindemann-matthies, P. (2010). The influence of an educational program on children's perception of biodiversity. The Journal of Environmental Education, 33(22), 22-31. https://doi.org/10.1080/00958960209600805

Monroe, M. C., Andrews, E., \& Biedenweg, K. (2007). A framework for environmental education strategies. Applied Environmental Education and Communication, 6, 205-216. https://doi.org/10.1080/15330150801944416

National Resource Center (2010). Identifying and promoting effective practices. http://strengtheningnonprofits.org/resources/guidebooks/Identifying\%20and\%20Promot ing\%20Effective\%20Practices.pdf.

North American Association for Environmental Education. (2004). Environmental education materials: Guidelines for excellence. https://naaee.org/sites/default/files/gl_ee_materials_complete.pdf

Ormond, C. G., Zandvliet, D., McClaren, M., Robertson, P., Leddy, S., \& Metcalfe, S. (2014). Environmental education as teacher education: Melancholic reflections from an emerging community of practice. Canadian Journal of Environmental Education, 19, 160-179. https://files.eric.ed.gov/fulltext/EJ1061976.pdf

Republic Act No. 9512 - National Awareness and Environmental Education Act of 2008

Stern, M., Powell, R \& Hill, D. (2013). Environmental education program evaluation in the new millennium: what do we measure and what have we learned?. Environmental Education Research 20(5), 581-611. https://doi.org/10.1080/13504622.2013.838749

Saima A. Sansaluna-Maulana. (2021). The Teaching Practices of Senior High School English Teachers in Maguindanao, Philippines. Randwick International of Education and Linguistics Science Journal, 2(3), 358-363. https://doi.org/10.47175/rielsj.v2i3.303

Wi, A. and Chang, C. (2019). Promoting pro-environmental behavior in a community in Singapore - from raising awareness to behavioural change. Environmental Education Research, 25(7), 1019-1037. https://doi.org/10.108013504622.2018.1528496 